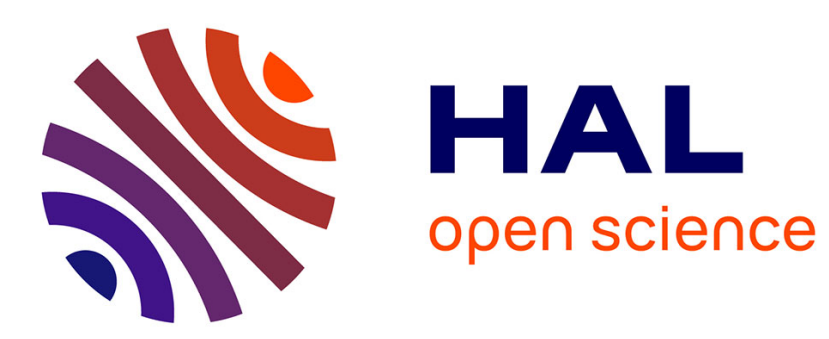

\title{
Last resort? Lobotomy operations in Israel, 1946-60
}

Rakefet Zalashik, Nadav Davidovitch

\section{To cite this version:}

Rakefet Zalashik, Nadav Davidovitch. Last resort? Lobotomy operations in Israel, 1946-60. History of Psychiatry, 2006, 17 (1), pp.91-106. 10.1177/0957154X06058593 . hal-00570839

\section{HAL Id: hal-00570839 \\ https://hal.science/hal-00570839}

Submitted on 1 Mar 2011

HAL is a multi-disciplinary open access archive for the deposit and dissemination of scientific research documents, whether they are published or not. The documents may come from teaching and research institutions in France or abroad, or from public or private research centers.
L'archive ouverte pluridisciplinaire HAL, est destinée au dépôt et à la diffusion de documents scientifiques de niveau recherche, publiés ou non, émanant des établissements d'enseignement et de recherche français ou étrangers, des laboratoires publics ou privés. 


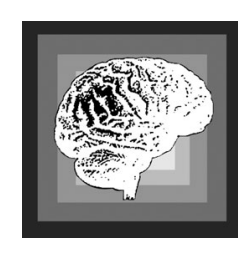

\title{
Last resort? Lobotomy operations in Israel, 1946-60
}

\author{
RAKEFET ZALASHIK \\ Tel Aviv University
}

NADAV DAVIDOVITCH*

Ben Gurion University

In this paper we examine lobotomy operations in mandatory Palestine and Israel between 1946 and 1960. The aim is to reconstruct the circumstances in which these operations were done, and to examine: which patients were lobotomized and why; how lobotomy was perceived by the local psychiatric profession; and the reasons for its decline. Apart from shedding new light on the history of lobotomy, which is usually analysed from the viewpoint of the USA and Europe, this study provides an opportunity to investigate the relation between various concepts of the healthy and ill body in the unique context of Israel, as an immigrant country influenced by its Zionist ideology.

Keywords: history of the body; immigration and health; Israel; lobotomy; psychiatry; Zionism

\section{Introduction}

As the historians Mark Jenner and Bertrand Taithe (2000) have emphasized, the history of medicine has almost always been concerned with the interpretation of sick bodies. It has been predicated upon the shifting definitions of normativity and normality, the normal and the pathological body (Canguilhem, 1989). Somatic concerns were already apparent in the pioneering work of historians of medicine such as Karl Sudhof, Henry Sigerist and Oswei Temkin. Yet none of this work cared to style itself 'the history of the body'. Only in the last two decades has 'the history of the body' become a recurrent theoretical basis for a long series of interdisciplinary researches in

* Address for correspondence: Department of Health Systems Management, Ben Gurion University, Beer Sheva, 84105, Israel. Email: mikinadv@post.tau.ac.il 
the history of medicine. ${ }^{1}$ In these works, the body, so often hidden as a 'natural', ahistorical and transparent given in our society, is itself deconstructed as a historical construct, as the primary locus upon which power has been inscribed. The construction of the various bodies - normal vs. pathological, hegemonic vs. marginalized - has vast political and social consequences. In the history of medicine, too, practices ranging from medical therapies to preventive medicine and hygiene, took their logic and power from the specific construction of the desired body.

A radical example of somatic practices in twentieth-century medicine was the introduction into the field of psychiatry of lobotomy operations, the surgical interruption of nerve tracts to and from the frontal lobe of the brain. The historiography of lobotomy is rich in attempts to explain why it became so popular in certain countries. Pressman (1998) agreed that lobotomy was 'a crude and reckless procedure devoid of any scientific justification', but he was unwilling to call it 'a medical mishap of epic proportions'. He reminded us that the usefulness of a therapy is contingent on the era in which it is applied, and that what is judged to work is specific to place, patients and doctors.

In this paper we examine lobotomy operations in mandatory Palestine and Israel between 1946 and 1960. The aim is to reconstruct circumstances that enabled the undertaking of lobotomy operations in the country and to answer the questions: who was lobotomized and why, how lobotomy was conceived by the psychiatric profession and what were the reasons for its decline. As will be discussed further, this case study also represents an opportunity to investigate the relation between various concepts of the healthy and ill body in the unique context of Israel, as an immigration country influenced by its Zionist ideology.

\section{The Israeli and Zionist context}

Pre-Israeli psychiatry in mandatory Palestine and Israeli psychiatry in its first years can be characterized as a hybrid form of colonial psychiatry and a national one. ${ }^{2}$ The colonialist perspective was manifested in the way the small psychiatric community in Palestine, which consisted of central European Jewish psychiatrists, had viewed the native population. Based on the conception that mental illnesses are diseases of civilization (see Porter, 1993: 590, 592), these psychiatrists shared the belief that they are the outcome of modern urban life which has alienated men from nature. They saw mental illnesses among the native population as a result of their difficulties in adjusting to the increasing modernization that Palestine experienced during the first decades of the twentieth century due to British Mandate (Halpern, 1939).

Contemporary statistics showed that Jewish immigrants suffered from mental diseases more than Arabs in general, and that Christian Arabs suffered from them more than Muslims did (Mills, 1932). The psychiatrists 
claimed that these data reflected the cultural state of each group in Palestine. According to their logic, Jews who came from Europe had a higher incidence of mental illness in the new country because they belonged to a modern civilization. Similarly, the constant involvement of Christian Arabs in Palestine in modern life - namely, their activity in trade, the increase of their education level and their growing participation in bureaucratic state mechanisms - resulted in the development of mental health problems. In contrast, the low percentage of mental diseases among Muslim Arabs was correlated to their relatively quiet agrarian life according to traditional patterns (see, for example, Halpern, 1938).

The national aspect of pre-Israeli psychiatry was expressed in the distinction made not only between Jews and Arabs, but also between native Jews and Jewish immigrants from Europe, and between Jewish Ashkenazi and 'Oriental'-Sephardic. The main assumption was that both native Jews and native Arabs suffer from the same kind of mental diseases and share a 'common oriental motorial line' (Herman, 1935). This was how psychiatrists contrasted mentally ill immigrants with the mentally ill from the 'old Jewish settlement' and the local Arabic population. This differentiation process was essential for the creation of the national 'new Jew' and its justification. ${ }^{3}$

We should remember that the Jewish psychiatrists in Palestine were not operating in a professional and social void. The rise of scientific antiSemitism, mainly in Europe, which perceived the Jewish race as degenerative and diseased, reshaped the discussion of identity among Jewish thinkers. The Zionist Movement also approached these questions of Jewish identity through the prism of the uniqueness of the Jewish race. ${ }^{4}$ Many Zionists, themselves influenced by the dominant voice of their time, came to see the Jewish body as degenerative and ill: physically and mentally, individually and collectively. ${ }^{5}$ The remedy for the 'psychopathology of the Jew', intended to improve the body and soul, was believed by many Zionists to be a return to a Jewish identity through immigration to Palestine, where a national Jewish home was to be established - a healthy society of equals. In this state the degenerative Jewish body - both individual and collective - could be cured of its various illnesses: physical, mental and social. ${ }^{6}$

The 'Oriental' Jew had a very small role in this worldview (Khazzoom, 2003; Shohat, 1997). The main human resources for future immigration were sought in Europe, and the 'Oriental' Jews were not part of the mainstream Zionist plan until World War II. This situation changed markedly after the extermination of most European Jews during the Holocaust and with the foundation of the state of Israel. Between May 1948 (the founding of the new state) and 1951, Israel experienced an influx that more than doubled its population. During this period a very diverse and very large group arrived: some 700,000 people, half from Europe and half from Africa and Asia (primarily Yemen, Iraq, Iran, Turkey, Libya, Tunis and Morocco). Immigration on this scale was unprecedented in modern times; even 
countries such as the USA and Canada had never absorbed such a large proportion of immigrants in such a short a time. This mass immigration to Israel presented the state with urgent practical problems. Within a few years the Jewish population of the state had to absorb hundreds of thousands of immigrants, many of them ill with diseases that required immediate hospitalization (Hacohen, 1994). As some recent works have shown, the health dimension played an important role in the social and cultural tensions among the various groups and in the melting-pot policy of the establishment (Davidovitch and Shvarts, 2004; Weiss, 2002). Another crucial aspect was the dramatic change in the demographic composition of the immigrant population due to the large numbers arriving from North Africa and other Arab countries. The 'Oriental'-Sephardic Jews now became the main demographic group of immigrants, thus imposing a challenge to the identity of the existing population, which was mainly of European origin, secular and often socialist.

\section{The beginning of lobotomy operations}

Lobotomy, the destruction of the frontal lobes, was invented by Egas Moniz, a Portuguese neurologist and Nobel prize winner, and was promoted extensively by Walter Freeman, an American neurologist. The success of lobotomy is attributed to several contemporary medical, historical and social conditions, such as the lack of other effective treatments, and the large number of mentally ill patients in state hospitals. The acceptance by the medical profession of such an irreversible procedure is traditionally viewed in the light of the somatic treatments developed in the first half of the twentieth century, for instance, hydrotherapy, malaria therapy, insulin coma, Metrazol convulsions and electroconvulsive therapy. ${ }^{7}$

Lobotomy was only one of the innovative somatic therapies imported to Palestine and adopted by the local psychiatric community: electroconvulsive therapy was first used in 1937/38, and a year later psychiatrists also began treating mentally ill patients with insulin shock (Halpern, 1949). These therapies were imported from Europe, and several of the Jewish psychiatrists had already gained some experience with the treatments before moving to Palestine in the late 1930s.

Lobotomy, on the other hand, was the first therapy imported to Palestine from the USA after World War II. This geographic change of influence was not just a technical one, but should be seen as part of the general shift that took place in the professional identity of psychiatrists in Palestine. Until the mid 1940s, these psychiatrists considered themselves as part of the European medical tradition, and especially as a continuation of the German one. This was a natural development, since most of the psychiatrists were educated in German medical faculties, and Germany was the most important psychiatric centre at the time. ${ }^{8}$ 
After the end of World War II, psychiatry in Palestine - and later in Israel - became American-oriented. This was a result of financial and organizational co-operation between Israelis and Americans, and the shift of the main arena of 'scientific' medicine, including psychiatry, to the USA and the simultaneous decline of German psychiatry. It was also a consequence of a significant break with European medicine in general, and with German psychiatry in particular, because of their role in euthanasia killings and other holocaust horrors.

The topic of lobotomy operations begins to appear in the pre-Israeli psychiatric literature only in 1944. Simon Fleischman, a local psychiatrist encouraged by the positive results presented the year before at a neurological society meeting in Chicago, evaluated lobotomy operation as an effective therapy for curing all sorts of obsessive disturbances. After presenting the new therapy to his colleagues in Palestine, he concluded:

... also in the negative results of lobotomy, we can hope that these are only teething troubles and they might be reduced as experience and research progress. The importance of the described treatment is enormously significant, especially if we keep in mind the unsuccessful means that we have now against mental diseases. (Fleischman, 1945: 143)

When lobotomy reached its 'golden age' in the USA in 1946/1947, four lobotomy operations had already been done in Palestine by Aharon Beller, a neurosurgeon who had emigrated from Vienna in 1938 and later became chief neurosurgeon of Hadassah Hospital. It can be assumed that he learnt about lobotomy procedure from the literature and used the Freeman-Watts technique. ${ }^{9}$

From 1948 onwards, lobotomy operations became an established therapy in Israel. This was possible through the foundation of two neurosurgical departments in the country: one in Hadassah Hospital in Jerusalem, which was reopened, and the other in Belinson Hospital near Tel-Aviv. The setting up of these new departments was a direct outcome of the 1948 war: many soldiers suffered from severe head injuries, and the existing medical departments could not provide proper treatment, so specialized neurosurgical units were needed. After the end of war, the departments began to perform lobotomy operations on mentally ill patients sent from state and private psychiatric institutions.

The significance of lobotomy as an innovative treatment - which had been introduced into the scientific Israeli domain and had become established as part of local psychiatric activity - was clear, and it was the main subject of the fourth conference of the Israeli Neuro-psychiatric Society in November 1949. At this meeting, 43 cases of lobotomy were presented by the staffs of the neurosurgical departments. Beller and Lipman Halpern, a psychiatrist and a prominent neurologist from Hadassah Hospital in Jerusalem, reported 22 cases of lobotomy operations conducted on schizophrenic patients from four private institutions. The neurosurgeon Heinrich Ashkenazi and the psychiatrist and 
neurologist Zvi Winnik, who belonged to Geha psychiatric hospital and the general hospital Belinson, both part of the General Sick Fund, presented 21 cases of schizophrenics and psychotics who underwent lobotomy. Both teams expressed satisfaction with the results, despite the death of one patient in each group.

These two presentations and the discussion which followed show how psychiatrists and neurosurgeons conceived lobotomy and the patients whom they perceived as favourable candidates for the operation. None of the conference participants doubted or criticized the new therapy. The only questions were when was the best timing to operate and on whom. One psychiatrist said that since lobotomy is a bodily mutilation, it should be conducted only in cases where there is nothing to lose. Another psychiatrist replied that 'it is inappropriate to call an operation, which is performed with the serious intention of helping someone medically, "mutilation"'. The speaker said that, in spite of the anatomical changes that the four speakers had discovered in some of the cases during the operation, no therapeutic opportunities should be missed, and 'there is no doubt that lobotomy might cause damage, but which operation does not? It is not clear that convulsive therapies are causing less damage' (Israeli Neuro-Psychiatric Society, 1951).

Most of the psychiatrists agreed that the operation should be performed on a patient only if his or her personality had not broken down completely. These psychiatrists used this fluid criterion in order to explain the negative results of lobotomy operations: when they failed it was due to the patients' personalities and not to the lobotomy operation or the psychiatrist or neurosurgeon.

Interestingly, some psychiatrists reported treating post-lobotomized patients, which proved to them that lobotomy operations are successful only if followed by intensive psychotherapy. The discussion ended with the conclusion that 'our experience with lobotomies is small but encouraging, especially since we were, and will be, successful in discharging those patients who, without an operation, would have stayed there forever' (Israeli Neuro-Psychiatric Society, 1951).

\section{Who was lobotomized and why?}

Lobotomy is considered to have been the most extreme therapy conducted on mental patients in the twentieth century. It was promoted with relative success at the time, although it lacked a strong scientific theoretical basis and it caused irreversible damage to the brain. Several historians have tried, therefore, to understand its appeal in the contemporary context. An important part of this understanding is to investigate who was subjected to the procedure, and what were the indications required to carry it out. In our case, the specific context of colonial and Zionist frameworks in an immigrant country provides the particular circumstances of lobotomy operations.

The first patient who underwent lobotomy in Palestine was a Jew from 
Egypt, who had already fallen ill in 1943 in Cairo where he was hospitalized and received 18 ECT treatments and Cardiazol for two months. In July 1944 he was admitted again, and due to a lack of improvement in his condition, was sent by his family to Kurt Blumental's asylum in Haifa. There he was diagnosed as 'schizophrenic combined with emotional attacks and stupidity'. After 35 sessions of insulin shock and 11 ECT treatments during one year, Blumental and Beller decided to perform a lobotomy as a last resort (Halpern, 1947). This operation and the next one on a 28 -year-old male patient - also schizophrenic - were considered to be successful. The second patient, it was proudly reported, was recruited to the army, 'participated in the 1948 war and was injured. Now serving without a fault in the IDF to the full satisfaction of his commanders' (Halpern, 1947). It is evident that the criteria of what should be counted as a successful operation were deeply influenced by the local perception of what is a normal and productive behaviour.

The 53 available documented cases of patients who underwent lobotomy operations between 1946 and 1953 do not allow generalizations to be made or firm conclusions to be drawn. However, they do illustrate a few characteristics and may function as a sample that indicates who was lobotomized, what the operative indications were, and whether the procedure was considered as successful and according to what criteria. ${ }^{10}$

Most of the operations took place in 1949, namely, when the first two neurosurgical departments in Israel were opened. All patients except one underwent lobotomy on both sides. Thirty patients $(57 \%)$ were women. Forty-three $(79 \%)$ were diagnosed as suffering from various types of schizophrenia. Other diagnoses were melancholia agitatis, paranoia and manic depression. One person was not a typical psychiatric patient: he suffered from phantom pain and underwent one-lobe lobotomy on the opposite side to the amputated limb.

Information about previous therapies attempted before the lobotomy was available for 27 of the 53 patients. Of these, three could not be treated with shock therapies due to physical limitations, 10 did not show any improvement after shock treatment and the rest showed a short-term improvement. In many cases, the indication for conducting a lobotomy operation was 'as a last resort'; in others the patient's family pressed for the operation to be done, an important factor in many psychiatric treatments, especially lobotomy.

It seems that the main indication for performing lobotomy in Israel was the failure, or the inconsistent effect of, other therapies such as ECT and insulin, mainly (though not entirely) in chronic mentally ill patients. In other words, lobotomy was used in Israel as a last resort. However, the concept of 'last resort' was very flexible and subjective, as illustrated by the next case, which was presented by Winnik and Ashkenazi in 1950. A 56-year-old woman - a married housewife with two children - was sent to be lobotomized after only 6 months of hospitalization in the psychiatric institute. She had been admitted to the institute after a suicide attempt and diagnosed as 
suffering from melancholia agita. She could not be treated with insulin shock as she had a gall-bladder disease, and she had not reacted to 12 sessions of ECT. Winnik and Ashkenazi (1950: 507) explained:

After taking into account all the factors of her condition, which seemed hopeless, we decided to perform lobotomy. In the post-lobotomy phase, the patient was very confused, incoherent and disorientated. A few days later, the anxiety was reduced and she gained weight. Mentally there was a certain state of apathy and inertia with a weak form of hallucinations.

In a follow-up examination a year later, Winnik and Ashkenazi have reported that 'the subjective state of the patient was normal, her appearance and behaviour were totally normal, she was fulfilling her tasks in the household, read newspapers and books' (p. 507). The gender aspect of what constituted normality was prominent - the first sign of 'normality' for this patient was that she could undertake housekeeping routines.

In 1957 Bental $^{11}$ published in Schweizer Archiv für Neurologie und Psychiatrie the results of lobotomy operations conducted on psychotic patients in comparison with their psychotic relatives who had not been lobotomized. The cases presented in this paper allow us to examine the categories of immigration and gender in the context of lobotomy operations in Israel. In one of the cases Bental describes three schizophrenic sisters who emigrated from Baghdad to Israel. It is important to remember that in this case the psychiatrist and his patients were from different cultures: the psychiatrist was an established immigrant who had arrived from central Europe in 1933 and was established in class and profession, in contrast to the immigrants from Iraq who had just arrived. This is how Bental described the cultural and family background of the three sisters, Louise, Margaret and Evelyn:

The milieu is typically oriental in which the father stands at the head of the patriarchal dynasty, beloved, frightening and hated. However, modern conceptions have also penetrated; although they have been 'only daughters' they were sent to a boarding school and learnt languages: French, Arabic, Hebrew, which they mastered more or less. The father spoke only Arabic and some Hebrew, the mother spoke only Arabic. In spite of this progress in their view, the daughters could marry only in the order of their age. That is why, in 1955, the adult daughter despite her mental defects was getting married in order to pave the way for the marriage of the younger ones. - To describe the parent as suffering from a schizoid personality would be inappropriate, since this point of view is very traditional. (Bental, 1957: 8)

The first daughter, Louise K., first became ill when she was 19 and was hospitalized for two months in a nerve clinic in Baghdad. In April 1945 the illness recurred and she became upset again, beat her father, threatened to commit suicide and was hospitalized again. In July that year she arrived in Palestine and was institutionalized in Blumental's hospital in Haifa. He 
described her behaviour as agitated, aggressive and sexual. After several treatments with insulin and ECT, her clinical condition was stabilized. The possibility of a lobotomy was rejected due to her family background, the evolution of the disease and the symptoms. In a follow-up examination, it seemed that Louise became a quiet schizophrenic.

The middle sister, Margaret K., was diagnosed by Bental as suffering from inferiority complex and 'not intelligent'. At the age of 17 she became psychotic and was hospitalized in an Iraqi psychiatric institution for three months. After insulin and ECT treatments, her condition improved. At the beginning of 1950 she went into Bental's hospital, and after five months of insulin and ECT sessions she had partly improved and was released. In March 1951 after two further hospitalizations when she was suffering from a catatonic state and aggressive attacks, it was decided to conduct a lobotomy:

It seemed to us that the second sister, Margaret, could perhaps be saved from the fate of the elder sister. The operation was an attempt to avoid such a tragic situation. On the other hand: negative developments and the family situation left no illusions concerning the chances of success. The indication for the operation was then only 'the lesser of two evils'. (Bental, 1957: 10)

The youngest sister, was hospitalized in Bental's institution during Margaret's treatment, and was also diagnosed as schizophrenic. She was not lobotomized since she reacted to a combined treatment of insulin and ECT. According to Bental's description 'the patient is very much interested in her treatment', even 'almost addicted to her treatment with insulin and E.C.T.'.

About two years after their treatment in his clinic, Bental made a followup visit to the sisters' house, where they were living with their parents. $\mathrm{He}$ concluded that the deterioration of Margaret, the lobotomized sister, could not have been prevented since 'the endogenous-genetic component was not influenced by the surgery' (Bental, 1957: 13).

Apart from the fact that that the case described is a tragic story of three sisters who suffered from mental illness, Blumental's description of his diagnosis and treatment illustrates the interrelations among the medical establishment (including psychiatrists, neurologists and neurosurgeons), the patients themselves and their families. It is probable that chronic cases of patients who did not fit the Israeli 'melting pot' plan during the first years of statehood in Israel were conceived as medical psychiatric cases which required harsh solutions if necessary. The determination of Bental to save his patient Margaret from the 'fate of her older sister' led him to perform the operation, even when admitting the low chance of successful surgery. His claim that the operation was 'the lesser of two evils' reflects the values behind his decision - what constituted worthwhile surgery, and what was the right choice between what he conceived as meaningless life and a calculated risk, knowing the physical damage that the operation caused. 
We cannot reconstruct the family discussions of the various therapeutic choices, since the family was almost entirely missing from Bental's narrative (except as part of the case history). But the fact that the parents brought their daughters to the clinic indicates that they agreed to the suggested treatments, including the lobotomy procedure. We should bear in mind that the family's part in lobotomy operations was a crucial one; various studies of the history of lobotomy and other somatic treatment show that the family frequently pleaded for the 'desperate' treatments, following years of despair in caring for a chronically ill relative. This was especially true in the first years when lobotomy operations were conducted and were seen as a promising and a progressive procedure.

In the case described above, the cultural tensions between Bental and his patients and their family is clear, in his explanations of both the aetiology of the illnesses and the consequences of treatment. The reason given by Bental for the lobotomy failure was related to the 'endogenous-genetic component', a component that could not have been influenced by the surgery, no matter how radical. Bental did not elaborate on how much this 'endogenous' component was related to the patient's ethnic and cultural background, but it is clear from his analysis that it played an important part in his understanding of the aetiology.

The performance of a wider destruction of the frontal lobe by a second operation was extremely rare in Israel (in contrast to the USA), and we know of only two cases. One of them was a woman, a holocaust survivor, who survived her first lobotomy in Budapest and three years later, after a relapse, was lobotomized again in Israel. The claims of Joel Braslow (1997) and Elaine Showalter (1985), that a higher proportion of women than men underwent lobotomy and had more than one lobotomy, cannot be supported in the case of Israeli lobotomy operations (Zalashik and Davidovitch, 2005). Although it seems that women were slightly more lobotomized than men, the difference is negligible since the proportion of women in psychiatric hospitals in Israel was higher than that of men. Furthermore, the argument that lobotomy was widely adopted in state psychiatric hospitals for economic reasons cannot be substantiated for Israel. Due to the historical roots of the development of psychiatric hospitalization in mandatory Palestine, $75 \%$ of mental patients were resident in a private institution in 1948, and only 55\% of patients were hospitalized in state psychiatric hospitals in 1955; the economic argument was mentioned only rarely in Israeli psychiatric literature. This is not to say that it did not exist, but it was not one of the fundamental reasons for the performance of lobotomy operations in Israel.

\section{Local criticism of lobotomy operations}

In general, scientific optimism concerning lobotomy was very common among Israeli psychiatrists and neurologists, and only a minority expressed 
various criticisms. The psychiatrist and psychoanalyst Daniel Dreifuss (1945) rejected lobotomy operations in general, and in particular for mentally ill people who suffered from non-organic diseases. He said that someone suffering from a real neurosis had the right to enjoy more humane treatment; a real cure for neurosis required a substantial liberation of personality and not its destruction. Moreover, he expressed the fear that a lobotomy operation would be taken as an immediate and easy solution for psychiatrists: they would turn to the surgical solution instead of investing time and resources in psychotherapy. Therefore he warned against this procedure without making a serious attempt at a real psychotherapeutic treatment.

Only a few psychiatrists, such as Blumental, were concerned about the substantial change in patient's personality. He was head of a small private psychiatric institution who therefore knew his patients well, and he seems to have felt the great loss suffered by a mental patient, who despite the disease, had a rich personality before being lobotomized. Such was the case of Susannah K. who suffered from manic depression and underwent lobotomy at the end of 1951. Bental (as Blumental was now called) described her after the operation as apathetic, someone for whom everything was lost, and acting more like a marionette. It was clear to him that in this case 'lobotomy caused a destruction of her highest layer of personality' (Bental, 1957: 19). Also, the psychiatrist Haim Eitan-Strak (1951) reported on post-lobotomized patients who had been improved by the operation and sometimes even recovered, but said that the price they paid was the destruction of their personality.

A unique aspect of criticism was sounded by the Israeli physician Mark Dvorzarsky, who rejected lobotomy for human and moral reasons. He wrote an article - based on publications of the French Jewish psychiatrist Henri Baruch, who dealt with ethical questions of the psychiatric profession - with the title 'What is a medical consciousness? What is a Hebrew Medicine? Psycho-surgery, a Danger to Man's personality?'. In it Dvorzarsky (1952) defined psychosurgery as a danger for the personality and warned against its misuse by psychiatrists. He was a general practitioner and not a psychiatrist. Moreover, he was a holocaust survivor who dedicated himself, as part of the rebuilding of an ethical and moral medicine, to warning the profession not to repeat crimes committed by physicians from all branches of medicine during the Nazi era. His criticism of lobotomy and its potential to be used as a punishment or as a human experiment came from this background. Furthermore, he perceived the operation as a means to reduce the free will of the patient and to degenerate his personality in a procedure which lacked a solid scientific basis, and was more a medical experiment than a therapy. Yet his voice was unique and his views were not shared by the medical profession.

In general, there was no regulation of the procedure of lobotomy in Israel. However, at the beginning of the 1950s, the Israeli Ministry of Health 
recommended that two psychiatrists should see every lobotomy candidate, and document the consultation in written reports. ${ }^{12}$

As time passed, even the main lobotomists started to express a more complex opinion of the procedure. A psychiatrist who had been one of the first to perform a lobotomy in Israel, and had been much in favour of it, said by the mid-1950s:

Prefrontal lobotomy, which was thought to open up new horizons for the
psychological understanding of the essence of psychosis and also for a
neurological clarification of the frontal lobes' functions, has fascinated
[...] our members. [...] At the society's conference, the experiences of
our members were presented for wide discussion which concluded with a
restrained optimism - in contrast to the exaggerated enthusiasm that
prevailed at the time concerning the results of the same operation in the
United States, for example, where it was almost considered to be a
routine treatment. And indeed, the developments of the last years have
very much proven the correctness of our meticulous approach in restricting
the operation to special patients only. (Israeli Neuro-Psychiatric Society,
1956: 74)

\section{Summary}

Lobotomy did not become a popular treatment in Israel in comparison with the USA and other countries. On the one hand, although it had the potential to become popular - since Israel was an immigrant society with acute lack of psychiatric beds and a very low budget for psychiatry - only a few hundred people underwent lobotomy between 1946 and 1960. On the other hand, these figures are not very low if we consider the total numbers of institutionalized mentally ill in the country: 2000 in 1948; 3000 in 1955; 5100 in 1959; and 5254 in 1961.

We claim that the number of lobotomy operations in Israel was relatively small because this imported innovative technique reached its golden age in Europe and the USA, when the local disciplines of psychiatry and mainly neurosurgery in Palestine and later in Israel were still in their infancy. Therefore Israeli psychiatry and neurosurgery missed the narrow time-window when lobotomy was a common and well accepted therapy. Furthermore, as in the USA, lobotomy quickly became a last-resort procedure, although we have shown in this paper that 'last resort' could be interpreted in a rather flexible way.

Another important factor in Israel was related to the role of the public and especially of the patients' families - which, in the USA at least, was a significant factor in the popularity of lobotomy - who were not always aware of the new technique of lobotomy. A rare criticism from the medical profession was related to the ethical aspects of lobotomy in the post-Holocaust era.

The other point which concerns historians of lobotomy is trying to 
understand why lobotomy almost vanished in the 1960s. Some claim that the poor long-term results of lobotomy operations and the introduction of antipsychotic drugs such as Chlorpromazine caused the decline of lobotomy. These reasons do not explain the situation with lobotomy in Israel. First, lobotomies were performed in Israeli psychiatric hospitals until the 1970s. Second, Chlorpromazine was introduced in December 1953, and in 1955 was already widely used in local psychiatric institutions. This was also the period when lobotomy operations were performed relatively frequently in Israel. So this question remains unanswered until scholars have access to a wider archival primary literature about lobotomy in Israel. This material will also enlighten us on issues such as the interaction between the medical establishment, physicians who were treating mentally ill patients, and the lobotomized patients and their families.

\section{Notes}

1. See, for example: Armstrong, 1983; Butchart, 1998; Gilman, 1991. These are just a few examples from a vast amount of literature published on the historical construction of the body. For a helpful overview from a sociological perspective, see also Turner, 1990.

2. On the history of psychiatry in Palestine and Israel, see: Vinic and Halpern, 1970; Witztum and Margolin, 2001; Zalashik, 2004, 2005.

3. See also Peled, 2002. For an incisive critique of Zionist discourses of masculinity, see Boyarin, 1997.

4. Though as Anita Shapira (1992) has pointed out, with respect to Nordau and his contemporaneous German Zionist colleagues, Nordau's 'acceptance of the anti-Semitic diagnosis did not entail concomitant acceptance of the racist deterministic prognosis preached by anti-Semitic ideologues.'

5. For the discourse of Jewish 'self-hatred', see the classic work by Sander Gilman, 1986.

6. On the various medical reactions to the 'Jewish problem', Zionist and non-Zionist, see: Efron, 1994; Hart, 2000.

7. On the development of somatic therapies, see: Braslow, 1997; Grob, 1994; Shorter, 1997; Valenstein, 1986.

8. On the German influences on the Jewish medical and psychiatric professions in Palestine, see: Baader, 2001; Gelber, 1990; Niderland, 1982.

9. This assumption is based (a) on the fact that Beller did not travel abroad for a fellowship in that period, and (b) on an interview with Bental's son, Haifa, December 2000. Learning medical practices through professional medical literature was not unusual at the time, especially when economic and political circumstances prevented frequent travels from the 'periphery'. The Department of Neurosurgery in Hadassah was established by Henri Wigderson at the end of 1941 and included only seven beds. It was reopened at the end of the 1948 war (Segal et al., 2005; Zionsit Archive, J113/2051).

10. There are no official data on the total number of lobotomy operations conducted in Israel. Our estimate is that about 200-300 such operations were done.

11. Blumental had changed his name to David Bental after the foundation of the state of Israel.

12. Israeli State Archive, G/ 4265/ 181/7. 


\section{References}

Armstrong, D. (1983) The Political Anatomy of the Body (Cambridge: Cambridge University Press).

Baader, Gerhard (2001) The impact of German Jewish physicians and German medicine on the origins and development of the Medical Faculty of the Hebrew University, Korot, 15, 9-45.

Bental, David (1957) Vergleich über den Verlauf von Psychosen bei lobotomierten und nicht lobotomierten Geschwisterm. Schweizer Archiv für Neurologie und Psychiatrie, 79, 1-26.

Boyarin, Daniel (1997) Unheroic Conduct: The Rise of Heterosexuality and the Invention of the fewish Man (Berkeley: University of California Press).

Braslow, Joel (1997) Mental Ills and Bodily Cures: Psychiatric Treatment in the First Half of the Twentieth Century (Berkeley: University of California Press).

Butchart, Alexander (1998) The Anatomy of Power: European Constructions of the African Body (London: Zed Books).

Canguilhem, G. (1989) The Normal and the Pathological, translated by Carolyn R. Fawcett (New York: Zone Book); originally published as: Le normal et le pathologique (Paris: Presses Universitaires de France, 1966).

Davidovitch, Nadav and Shvarts, Shifra (2004) Health and hegemony: preventive medicine, immigration and the Israeli melting pot. Israel Studies, 9, 150-79.

Dreifuss, Daniel (1945) [Brain surgery or psychotherapy?] Harefuah, 29, 128-9 (in Hebrew).

Dvorzarsky M. (1952) [What is a medical consciousness? What is a Hebrew medicine?] Niv Harofe, 7-8, 67 (in Hebrew).

Efron, John M. (1994) Defenders of the Race: Fewish Doctors and Race Science in Fin-de-Siècle Europe (New Haven and London: Yale University Press).

Fleischman, Simon (1945) [The phenomenon of obsessions and the problem of their essence in relation to new therapeutic means]. Harefuah, 28, 141-3 (in Hebrew).

Gelber, Y. (1990) [New Homeland: Immigration and Absorption of Central European ferws, 1933-1948] (Jerusalem: Ben-Zvi Memorial Foundation; in Hebrew).

Gilman, S. (1986) Fewish Self-hatred: Anti-Semitism and the Hidden Language of the Ferws (Baltimore: Johns Hopkins University Press).

Gilman, S. L. (1991) The few's Body (New York: Routledge).

Grob, Gerald N. (1994) The Mad Among Us: A History of the Care of America's Mentally Ill (Cambridge, MA: Harvard University Press).

Hacohen, Dvora (1994) [Immigrants in Turmoil: The Great Aliyah and its Absorption in Israel. 1948-1953] (Jerusalem: Ben-Zvi Institute; in Hebrew).

Halpern, Lipman (1938) Some data of the psychic morbidity of Jews and Arabs in Palestine. American fournal of Psychiatry, 94, 1215-22.

Halpern, Lipman (1939) [Psychic morbidity among the Jews in Erez Israel]. Harefuah, 12, 203-19 (in Hebrew).

Halpern, Lipman (1947) [Oedema in lower limbs after lobotomy]. Harefuah, 32, 63-4 (in Hebrew).

Halpern, Lipman (1949) Electroshock as a diagnostic aid in schizophrenia. Monatschrift fur Psychiatrie und Neurologie, 118, 61-4.

Hart, Mitchell B. (2000) Social Science and the Politics of Modern Fewish Identity (Stanford: Stanford University Press).

Herman, Heinz (1935) [Ten years of experience in psychiatric work in Jerusalem]. Harefuah, 10, 338 (in Hebrew). 
Israeli Neuro-Psychiatric Society (1951) [Report of Fourth Conference, 1949]. Harefuah, 39, 92-8 (in Hebrew).

Israeli Neuro-Psychiatric Society (1956) [Report of Sixth National Conference]. Harefuah, 50, 73-6 (in Hebrew).

Jenner, Mark S. R. and Taithe, Bertrand O. (2000) The historiographical body. In R. Cooter and J. Pickstone (eds), Companion to Medicine in the Twentieth Century (London and New York: Routledge), 187-200.

Khazzoom, Aziza (2003) The great chain of Orientalism: Jewish identity, stigma management, and ethnic exclusion in Israel. American Sociological Review, 68, 481-510.

Mills, E. (1932) Census of Palestine 1931, Vol. I (Jerusalem: printed by the Greek Convent \& Goldberg Presses), 230.

Niderland, D. (1982) [The influence of doctors from the German immigration on the development of medicine in Palestine]. Unpublished $\mathrm{PhD}$ thesis, Hebrew University, Jerusalem (in Hebrew).

Peled, Rina (2002) ['The New Man' of the Zionist Revolution: Hashomer Hatzair and its European Roots] (Tel Aviv: Am Oved; in Hebrew).

Porter, R. (1993) Diseases of civilization. In W. F. Bynum and R. Porter (eds), Companion Encyclopedia of the History of Medicine, Vol. 1 (London and New York: Routledge), 585602.

Pressman, J. (1998) Last Resort: Psychosurgery and the Limits of Medicine (Cambridge: Cambridge University Press).

Segal, R., Shoshan, Y., Israel, Z., Spektor, S., Cohen, J., Fraifeld, S. and Umansky, F. (2005) Neurosurgery at the Hadassah-Hebrew University Medical Center in Jerusalem. Neurosurgery, 56, 1135-48.

Shapira, A. (1992) Land and Power: The Zionist Resort to Force, 1881-1948, translated by William Templer (New York: Oxford University Press); originally published as: Herev Hayona: Hazionut ve'Ha'Ko'akh 1881-1948 (Tel-Aviv: Am Oved, 1992).

Shohat, Ella (1997) The narrative of the nation and the discourse of modernization: the case of Mizrahim. Critique, 10, 3-18.

Shorter, Edward (1997) A History of Psychiatry: From the Era of the Asylum to the Age of Prozac (New York: John Wiley).

Showalter, Elaine (1985) The Female Malady: Women, Madness and English Culture (New York: Pantheon Books)

Strak-Eitan, Haim (1951) Report of Fourth National Conference (1951). Harefuah, 39, 92-3 (in Hebrew).

Turner, B. (1990) Recent developments in the theory of the body. In M. Featherstone, M. Hepworth and B. Turner (eds), The Body: Social Process and Cultural Theory (London: Sage).

Valenstein, E. (1986) Great and Desperate Cures: The Rise and Decline of Psychosurgery and other Radical Treatment for Mental Illness (New York: Basic Books).

Weiss, Meira (2002) The Chosen Body: The Politics of the Body in Israeli Society (Stanford: Stanford University Press).

Winnik, H. and Halpern, B. (1970) [The development of psychiatry in Israel]. Korot, 5, 188-96 (in Hebrew).

Winnik, M. and Ashkenazi, H. (1950) Sur certaines indications vitales de la lobotomie. Revue Neurologique, 83, 506-9.

Witztum, E. and Margolin, J. (2001) [Chapters in the history of psychiatry in Palestine and its neighbourhood]. Harefuah, 140, 790-4 (in Hebrew).

Zalashik, R. (2004) [Pioneering psychiatry: Zionist newcomer and Jewish psychiatry in Palestine in the 1920s]. Israel, 6, 63-82 (in Hebrew). 
Zalashik, R. (2005) Psychiatry, ethnicity and migration: the case of Palestine 1920-1948. Dynamis, 25, 403-22.

Zalashik, R. and Davidovich, N. (2005) [Historical perspectives on immigration, gender and mental health: A glance into a multi-cultural society]. In R. Lev, J. Cwikel and N. Barak (eds), Guard your Soul. Mental Health among Women in Israel (Jerusalem: Brookdale Press), 21-41 (in Hebrew). 